ELK

Asia Pacific Journals

$\underline{\text { www.elkjournals.com }}$

\title{
FINANCIAL PERFORMANCE ANALYSIS OF DIFFERENT BANKING SECTOR WITH REFERENCE TO PROFITABILITY, LIQUIDITY AND RISK \& SOLVENCY: A COMPARATIVE ANALYSIS OF BANKING SECTOR OF PAKISTAN: (2011-2015)
}

\begin{tabular}{|c|c|c|c|c|c|}
\hline $\begin{array}{l}\text { Muhammad } \\
\text { Bilal Ahmad } \\
\text { Ph.D. } \\
\text { (Scholar) } \\
\text { Hailey College } \\
\text { of Commerce, } \\
\text { University of } \\
\text { the Punjab, } \\
\text { Lahore } \\
\text { bilalaahmad22 } \\
\text { 0@gmail.com }\end{array}$ & $\begin{array}{l}\text { Zahid Iqbal } \\
\text { Ph.D. } \\
\text { (Scholar) } \\
\text { Hailey } \\
\text { College of } \\
\text { Commerce, } \\
\text { University of } \\
\text { the Punjab, } \\
\text { Lahore } \\
\text { zahidiqballak } \\
\text { @ gmail.com }\end{array}$ & $\begin{array}{l}\text { Hafiz Fawad } \\
\text { Ali } \\
\text { Institute of } \\
\text { Business } \\
\text { Administration } \\
\text { University of } \\
\text { the Punjab, } \\
\text { Lahore } \\
\text { fawadali94@h } \\
\text { otmail.com }\end{array}$ & $\begin{array}{l}\text { Sohail Aslam } \\
\text { Ph.D. (Scholar) } \\
\text { Hailey College } \\
\text { of Commerce, } \\
\text { University of } \\
\text { the Punjab, } \\
\text { Lahore } \\
\text { zahidiqballak@ } \\
\text { gmail.com }\end{array}$ & $\begin{array}{l}\text { Fatima } \\
\text { Iqbal } \\
\text { Ph.D. } \\
\text { (Scholar) } \\
\text { Hailey } \\
\text { College of } \\
\text { Commerce } \\
\text { University } \\
\text { of the } \\
\text { Punjab, } \\
\text { Lahore } \\
\text { zahidiqbal } \\
\text { lak@ gmai } \\
\text { l.com }\end{array}$ & $\begin{array}{l}\text { Maria } \\
\text { Quibtia } \\
\text { Ph.D. } \\
\text { (Scholar) } \\
\text { Hailey } \\
\text { College of } \\
\text { Commerce, } \\
\text { University } \\
\text { of the } \\
\text { Punjab, } \\
\text { Lahore }\end{array}$ \\
\hline
\end{tabular}

\section{Abstract}

The rudimentary aim of this study is to investigate the financial performance and provision of timely information to all the stakeholders of different banking sectors on the basis of profitability, liquidity and risk \& solvency. In this study six categories of banks were taken as sample including 05 public sector banks, 22 private banks, 04 specialized banks, 04 foreign banks, 11 microfinance banks and 7 investment banks. Ratio analysis tool applied to investigate the financial performance of aforementioned banking sector that are working in Pakistan. According to the findings of study Specialized banking sector leading on all other banking sector with respect to profitability. Foreign banking sector dominating on all other banking sector with reference to liquidity, whereas investment banking sector performance is better than all other banking sector in the context of risk \& solvency. Mean value of all profitability ratios, liquidity ratios and risk \& solvency ratios also used to measure the overall performance. However foreign banking sector dominating on all others banking sectors with respect to overall performance on the basis of profitability ratios, liquidity ratios and risk \& solvency ratios.

Key words: Ratio Analysis, Profitability, Liquidity, Risk \& Solvency. 


\section{INTRODUCTION}

Banking sector is the backbone of economy as this sector fulfill the capital requirement of business community on the basis of its financial soundness. Profitability, liquidity and risk \& solvency of different banking sectors have equal importance for business community and other stakeholder including depositors, investors, branch manager, government authorities and regulatory bodies. On the basis of the findings of this study various aforementioned stakeholder can enhance their financial performance through the provision of better decision making. Government authorities and regulatory bodies will also observe the financial soundness of different banking sector working in Pakistan. According to Hassan \& Bashir (2003) critical performance of banking sector on the basis of profitability, liquidity and risk \& solvency have equal importance for all stakeholders of different banking sectors.

Basic purpose of this piece of research work is to evaluate the financial performance of different banking sector working in Pakistan including 5 public sector banks, 22 private banks, 4 specialized banks, 4 foreign banks, 11 microfinance banks and 7 investment banks. Ratio analysis techniques applied in this study to measure the financial performance of aforementioned banks on the basis of profitability, liquidity and risk
\& solvency. As suggested by Samad \& Hassan (2000) one of the most widely used techniques to observe the financial performance of banking sector is the ratio analysis technique. In this study comparative analysis of all banking sector working in Pakistan was steered by using the profitability ratio (Return on assets, return on equity and price to expense ratio), liquidity ratio (Loan to deposit ratio, current ration and current assets ratio) and risk \& solvency ratio (Debt to equity ratio, debt to total assets ratio and equity multiplier). The detail regarding each category of ratio and its subsequent types are given as under.

\section{A. Profitability Ratios:}

Profitability ratios revealed the capacity of business regarding earning profit by deducting all direct cost, direct expenses and other indirect expenses during the specific period of time. As recommended by Van Horne (2015) profitability ratios can be calculated by taking the total assets, total equity and operating expenses as denominator to observe the efficiency of total assets, total equity and maintaining the provision of profitability with reference to payment of operating expenses. Higher the profitability ratios indicate higher performance and lower the value of profitability ratios indicating low performance. In this study three types of 
profitability ratios applied to measure the financial performance of different banking sector that are operating in Pakistan including Return on Assets (ROA), Return on Equity (ROE), and Profit to Expense Ratio (PER). The details regarding each types of profitability ratios are given as under.

\section{1) Return on Assets (ROA):}

Value of profit against the value invested in total assets or in other words input in form of profit against the value of output or investment made in total assets is referred as Return on Total Assets (ROA). As recognized by Van Horne (2015) inflow in form of profitability against the value of total assets by deducting all direct and indirect expenses is referred as Return on Total Assets (ROA). Samad \& Hassan (2000) stress that process of converting assets into profitability through effective utilization of assets is referred as return on total assets. Greater the value of return on total assets signposts effective utilization of total assets and lower the value of return on assets is the sign of poor utilization of assets to generate the profit. Return on Assets can be calculated by using the following formula.

ROA $=\underline{\text { Net Profit after Tax }} \times 100$

Total Assets

\section{2) Return on Equity (ROE):}

Return on equity is the inflow in form of percentage profit against the value of amount invested in total equity is referred as return on equity (Van Horne, 2015). Input (Profit) against the value of output (Capital) is called return on equity (Samad \& Hassan, 2000). Efficiency of management of the organization also associated with the effective utilization of capital to generate profit (Sabi, 1996). Higher the value of return on equity linked with higher financial performance and lower the value of return on equity indicates the lower financial performance. Sabi (1996) proposed that return on equity can be calculated by using the following formula.

\section{$\mathbf{R O E}=\ldots+$ Net Profit after Tax $\_\_\times 100$ \\ Total Shareholder Equity}

\section{3) Profit to Expense Ratio (PER):}

Profit to expense ratio representing availability of profit to meet the operating expenses. Here operating profit mean is the profitability of an organization before deducting tax and interest. Efficiency of bank to control their operating expenses associated with the profit to expense ratio. Cost effectiveness and efficiency of banks with reference to control the expenses associates with the higher value of profit to expense ratio, whereas lower the value of 
profit to expense ratio indicates that banks fail to control their controlling expenses and have lack of profit to pay the operating expenses (Samad \& Hassan, 2000). Price to Expense Ratio (PER) Can be measure by using under mentioned formula.

\section{$\mathbf{P E R}=\underline{\text { Profit Before Tax }} \times 100$ \\ Operating Expenses}

\section{B) Liquidity Ratios:}

Ratios that represents the Capacity of banks regarding payment of current liabilities and current obligation is referred as liquidity ratios. Defaulting situation, financial crisis and financial distress also associated with liquidity ratio (Ross, Westerfield, Jaffe, 2005). Through proper management of cash and better debtor system liquidity position can be enhanced. Generally, an inverse relationship between the liquidity ratios and financial crisis was observed. Higher value of liquidity ratios except Loan to Deposit Ratio (LDR) leads to more capacity to pay the current liabilities (Higher Liquidity Position) and vice versa. Liquidity position of different banks also based on types of account being operated by different customer, for instance in case of large number of current accounts indicates higher risk as in case of current account at any time customer can withdraw whole amount without given a prior notice. In case of saving and fixed deposit account intensity of risk with reference of liquidity is lower because in case of saving account and fixed deposit account customer cannot withdraw whole amount without given a prior notice as per Banking Ordinance 1962. Samad \& Hussain (2000) recognized that Liquidity position of banks based on the amount of deposit and amount of withdrawal, in case of more deposit liquidity improve and will adversely affect through more withdrawal. The detail regarding each type of liquidity ratio including Loan to Deposit Ratio (LDR), Current Ratio (CR) and Current Assets Ratio (CAR) is given as under.

\section{4) Loan to Deposit Ratio (LDR):}

Loan to Deposit Ratio (LDR) is an important criterion used to observe the liquidity position of different banking sector. Here the percentage of total advances or total financing made by banks out of total deposit received is referred as Loan to Deposit Ratio (LDR). Here negative and significant relationship between the Loan to Deposit Ratio (LDR) and liquidity position of banks was observed. Liquidity position will be lower or adverse in case of higher Loan to Deposit Ratio (LDR), because higher ratio means banks made more advances or made more financing as compare to its total deposit, whereas a bank will be considered financially sound with respect to liquidity position if the value of Loan to Deposit 
Ratio (LDR) is lower, because bank sanctioned fewer loan or made less investment out of its total deposit. Loan to Deposit Ratio can be calculated by using the following formula.

\section{LDR $=\underline{\text { Total Advances } / \text { Total Financing }} \times 100$}

\section{Total Deposit}

\section{5). Current Ratio (CR):}

Current Ratio (CR) is another important aspect used to investigate the liquidity position of different banking sectors working in Pakistan. Here the current ratio indicates the percentage of total deposit being saved by bank in form of cash in hand or deposited in other banks accounts. Current Ratio and liquidity position have positive and significant relationship with the liquidity position of banks. Higher the value of Current Ratio (CR) stated higher liquidity position, because in case of higher value banks maintain and save more cash out of total deposit, whereas lower liquidity position associated with the lower value of current ratio because in case of lower value banks fail to save the amount of total deposit in form of cash himself or in other banks. Formula regarding calculation of Current Ratio (CR) is given as under.

$\mathrm{CR}=\underline{\text { Cash \& Accounts with Bank }} \times 100$

\section{Total Deposit}

\section{6). Current Assets Ratio (CAR):}

Current Assets Ratio (CAR) is another important criterion that is associated with the liquidity position of banking sectors. Here the percentage of current assets against the value of total assets is referred as Current Assets Ratio (CAR). Positive and significant association between the Current Assets Ratio (CAR) and liquidity position of banks was found in various studies. Here higher the value of Current Assets Ratio (CAR) indicates the higher liquidity position and higher liquidity position can be maintained by increasing the value of current assets against the value of total assets, whereas lower the value of liquidity ratio associated with lower liquidity that resulting if a banks fail to maintain enough current assets against the value of total assets. Current Assets Ratio (CAR) can be calculated by using the following formula.

$$
\mathbf{C A R}=\frac{\text { Current Assets }}{\text { Total Assets }} \times 100
$$

\section{Risk \& Solvency Ratios:}

Risky and solvency is an important aspect of banks as the profitability depends on the risk taken by the specific business organization. Risk and profitability have significant positive relationship, higher risk leads to higher profitability and higher chances of financial crisis or financial 
distress, whereas lower risk leads to low profitability and less chances of financial distress. Risk and solvency ratios widely used to access the performance of business with reference to risk factor and for this purpose various types of risk and solvency ratios used. Debt financing is an important part of capital structure as the profitability increase due to the significant tax advantages gain by business due to debt financing (Ross, Wedsterfield, and Jaffe, 2005). Most common and widely used risk \& solvency ratio including Debt to Equity Ratio (DER), Debt to Total Assets Ratio (DTAR) and Equity Multiplier (EM).

\section{7) Debt Equity Ratio (DER):}

How many times the total debts are of the total shareholder equity. Debt to Equity Ratio (DER) also indicates the capacity of banks regarding facing the financial crisis and financial shocks. Higher chances of financial crisis, default and financial stocks are associated with the higher value Debt to Equity Ratio (DER) whereas, financial soundness and strength associated with the lower value of Debt to Equity Ratio (DER). Debt to Equity Ratio (DER) can be calculated by using the following formula.

$$
\text { DER }=\frac{\text { Total Debt }}{\text { Shareholders' Equity }}
$$

\section{8). Debt to Total Assets Ratio (DTAR):}

Percentage of total debts to finance the total assets is referred as Debt to Total Assets Ratio (DTAR). Attraction of different opportunity and getting additional finance can be possible with the Debt to Total Assets Ratio (DTAR) but at the cost of higher risk and higher chances of financial crisis and higher financial distress. Higher the value of Debt to Total Assets Ratio (DTAR) indicates the higher risk, whereas lower the value of Debt to Total Assets Ratio (DTAR) is a sign of lower risk. Value of Debt to Total Assets Ratio (DTAR) can be calculated by using the following formula.

$$
\mathbf{D T A R}=\frac{\text { Total Debts }}{\text { Total Assets }}
$$

\section{9). Equity Multiplier (EM):}

Equity Multiplier (EM) express that how many times of total assets are of the total shareholder equity. Equity Multiplier (EM) shows association between the total assets and shareholder equity. Positive and significant relationship was observed between the Equity Multiplier (EM) and risk factor. Higher the value of Equity Multiplier (EM) associates with higher risk whereas lower risk factor linked with lower value of Equity Multiplier (EM). Value of Equity Multiplier (EM) can be measured by using the following formula. 
$\mathbf{E M}=$

Total Assets

Total Shareholders' Equity

\section{LITERATURE REVIEW}

Moin (2008) stress that one of the most important reliable techniques used to make comparison of different banks sector is the ratio analysis. Some important ratios that are commonly used including profitability ratio (Return on Assets, Return on Equity \& Profit to Expense Ratio) liquidity ratio (Loan to Deposit Ratio, Current Ratio, Current Assets Ratio) and risk \& solvency ratio (Debt to Equity Ratio, Debt to Total Assets Ratio \& Equity Multiplier). Flaming et al. (2009) mentioned that a key indicator to access the financial performance of different banks is the profitability ratio like Return on Assets (ROA), Return on Equity (ROE) and Profit to Expense Ratio (PER). Hassan \& Bashir (2003) argue that liquidity position of banks is an important indicator as liquidity has a significant relationship with the profitability. Liquidity indicator including amount of loan or financing out of total deposit, cash or cash equaling out of total deposit and percentage of current assets out of total assets that can be measure by using different types of liquidity ratio including Loan to Deposit Ratio (LDR), Current Ratio (CR) and Current Assets Ratio (CAR). Alexandru et al. (2008) suggested that Return on Assets (ROA),
Return on Equity (ROE) and Profit to Expense Ratio (ROE) is important indicator used to investigate the profitability position of different banks. Iqbal (2001) stress that financial comparison in banking sector on the basis of profitability can be made by using the profitability ration including Return On Assets (ROA), Return on Equity (ROE) and Price to Expense Ratio (PER). Samad \& Hassan (1999) propose that risk is an important factor as the profitability based on risk factor exists in business organization. Risk factor can be assessed by using the various financial ratio including Debt to Equity Ratio (DER), Debt to Total Assets Ratio (DTAR) and Equity Multiplier (EM).

Tihomir (2001) stress that profitability is the prime indicator used to observe the financial performance that can be measured by using the various types of profitability ratio including Return on Assets (ROA), Return on Equity (ROE) and Profit to Expense Ratio (PER). Moin (2008) recommended that profitability, liquidity and risk \& solvency are an important indicator as significant relationship was observed between them. Therefore, profitability ratio, liquidity ratio and risk \& solvency ratio used to make a comparison of different banking sector. Metwally (1997) examined that one of the most important criterion used to observe the financial performance is the ratio analysis 
and various types of ratio which represent profitability, liquidity and risk \& solvency. Javed et al. (2011) claim that for comparative analysis data can be collected from various financial statement (Porift and loss account, retain earning statement, balance sheet and cash flow statement) that help to calculate the profitability ratio, liquidity ratio and risk \& solvency ratio. Javed et al. (2011) examined that one of the most important indicator used to observe the financial performance is the profitability and profitability can be calculated by using the various types of profitability ratio including Return on Assets (ROA), Return on Equity (ROE) and Profit to Expense Ratio (PER). Hassan \& Bashir (2003) conducted a study to access the financial performance with reference to utilization of total assets and total equity to generate the profit. They suggested that effective utilization of assets can be checked by using the Return on Assets (ROA) and effective equity utilization can be access by using the Return on Equity Ratio (ROE). Hempel and Simonson (1998) insist that ratio analysis is one of the important indicator used to make a comparative analysis between different banks. Different types of ratio including profitability ratio, liquidity ratio and risk \& solvency ratio.

Khrawish (2011) percentage of profit against the value of total assets is referred as Return on Assets (ROA) and percentage of profit against the value of total equity is referred Return on Equity (ROE) which are the important indicator of profitability. Samad (2004)_recommended that various techniques used to access the financial performance including ratio analysis. Different ratio used to measure the different aspects of financial performance. For Instance, profitability can be measured by using the Return on Total Assets (ROA), Return on Total Equity (ROE) and Price to Expense Ratio (PER). Loan to Deposit Ratio (LDR), Current Ratio (CR) and Current Assets Ratio (CAR) used to observe the liquidity position whereas risk and solvency position can be accessed by using Debt to Equity Ratio (DER), Debt to Total Assets Ratio (DTAR) and Equity Multiplier (EM). Iqbal (2001) acknowledge that comparative analysis can be made on the basis of profitability, liquidity and risk $\&$ solvency ratios as significant relationship between these ratios with respect to measurement of performance of different banking sector was observed. Profitability ratio indicates the return against total assets or total equity or availability of profit to pay the operating expenses. Liquidity expresses the capacity of banks regarding payment of its current liabilities and short term obligation whereas risk and solvency indicates the present debt used in capital structure. Moin (2008), Sammad (2004) 
and Hassan (1999) observe that significant positive relationship was observed between the risk and profitability. Higher risk indicates high profitability and vice versa. Risk \& solvency can be assessed by using the different risk \& solvency ratio including Debt to Equity Ratio (DER), Debt to Total Assets Ratio (DTAR) and Equity Multiplier (EM). Awan (2009) argue that various types of ratio including profitability ratio, liquidity ratio and risk \& solvency ratio also used in different situation including purchase and selling, amalgamation, retirement of partner, admission of new partner etc.

\section{METHODOLOGY}

In order to access the financial health of banks ratios and percentage methods are used mainly. This study employed ration analysis in order to conduct inter-bank comparison. According to the study of Lader and Asarpota (2007) ratio analysis is the key indicator that can be used to measure the performance of different banking sectors. This study was conducted to make an inter banks comparison of different banking sectors working in Pakistan. To meet the purpose of study secondary data from audited financial statements of banks was collected for the period 2010-2014. According to the study conducted by Samad \& Hassan (2000) inter banks financial performance of banking sector can be observed by using the various types of financial ratio including Profitability ratio (ROA, ROE \& PER) liquidity ratio (LDR, CR \& CAR) and risk \& solvency ratio (DER, DTAR \& EM). In this study inter banks comparison of all banks was conducted by using the above mentioned types of ratios including profitability, liquidity and risk \& solvency.

\section{a. Theoretical Framework: (Ref}

Figure- 1)

\subsection{Objectives of the Study:}

This study helps in channelizing resources in future regarding deposit, finances, investment $\&$ others banking resources. However, the significant objectives of the study are given as under.

$>$ Which of the following banking sector is relatively more profitable?

$>$ Whish of the followings banking sector is relatively more liquid?

$>$ Which of the following banking sector is riskier? (Below Ref-

\section{Sample of the Study 3.3)}

\section{FINDING AND CONCLUSION:}

\section{a. Return on Assets (ROA):}

Return on Assets (ROA) indicates that percentage of profit against the amount invested in total assets. Following results reflect that according to the mean value of last five-year public sector banks get 
$0.97 \%$, private banks $1.35 \%$, specialized banks $1.94 \%$, foreign banks $1.24 \%$, microfinance banks $1.41 \%$ and investment banks bearing loss $-2.83 \%$ against Rs. 100 amount invested in total assets. With reference to Return on Assets (ROA) specialized banks dominating on all banks with respect to profitability and effectively utilized of its assets to generate profit because the Return on Assets Ratio (ROA) of specialized banks is greater than the all other banks. (Ref Table- 1)

\section{b. Return on Equity (ROE):}

Utilization of equity to generate the profitability or percentage of profit against the value of amount invested in equity is referred as Return on Equity (ROE). Higher value of Return on Equity (ROE) is a sign of effective utilization of equity to generate profit. Following results shows that public sector banks, private banks, specialized banks, foreign banks, microfinance banks \& investment banks gain Rs. 13.75, Rs. 15.74, Rs. 66.46, Rs. 9.71, Rs.5.6. and 21.36 respectively. However according to the mean value of last five year specialized banks dominating on all banks with 66.46 of profit against Rs. 100 invested in total equity. (Ref Table- 2)

\section{c. Profit to Expense Ratio (PER):}

Capacity to pay the operating expenses out of operating profit (Profit before interest and tax) is referred as Profit to Expense Ratio (PER). Means Company has more operating profit to pay the operating expenses. Following results reflecting that public sector banks have Rs. 47.51, private banks Rs. 81.79, specialized banks Rs. 63.33, foreign banks Rs. 84.59, microfinance banks Rs. 16.21 and Investment banks do not have any amount to pay the operating expenses or bearing loss Rs. -86.47 against the value of Rs. 100 operating expenses. Therefore, according to mean value foreign banks dominating on all banks as the foreign banks have Rs. 84.59 operating profit to pay Rs. 100 operating expenses which is higher than all others banks. (Ref Table- 3)

\section{d. Loan to Deposit Ratio (LDR):}

Loan to Deposit Ratio (LDR) is the percentage of total loan sanctioned/total advances out of total deposit received. Lower the value of LDR means more liquidity and vice versa. According to the following results out of Rs. 100 deposit public sector banks made advances Rs. 53.24, private banks Rs. 48.52, specialized bank Rs. 452.64 (Specialized banks advances higher because specialized banks used Govt. sources for advances besides the total deposit), foreign banks Rs. 40.56, 
microfinance banks Rs. 88.74 and Investment banks Rs. 10.70. However according to the mean value of last year investment banks dominating on all other banks because of lower value of Loan to Deposit Ratio that is R. 10.70. (Ref Table4)

\section{e. Current Ratio (CR):}

Percentage of cash in hand or cash in other banks out of total deposit is called Current Ratio. Higher the value of Current Ratio (CR) means higher the liquidity and vice versa. Therefore, according to under mentioned results public sector banks kept cash in hand or in cash other banks Rs. 12.86, private banks Rs. 11.77, specialized banks Rs. 67.88, foreign banks Rs. 27.45, microfinance banks Rs. 32.95 and Rs. 3.57 out of each value of Rs. 100 deposit. Therefore, specialized banks dominating on all other banks with respect of Current Ratio (CR) because the specialized banks kept Rs. 67.88 as cash in hand or in other banks out of total deposit, which is higher than all other banks. (Ref Table- 5)

\section{f. Current Assets Ratio (CAR):}

Portion of current assets against the value of total assets is referred as Current Assets Ratio (CAR). Higher liquidity associated with the higher value of Current Assets Ratio (CAR). Under mentioned results reveals that against Rs. 100 of total assets public sector banks current assets value is Rs. 98, private banks Rs. 97.58, specialized banks Rs. 96.73, foreign banks Rs. 99.38, microfinance banks Rs. 96.50 and investment banks Rs. 64.59. However foreign banks getting superior position on all other banks with respect to Current Assets Ratio (CAR) due to higher value which are 99.38. (Ref Table- 6)

\section{g. Debt Equity Ratio (DER):}

Debt to Equity Ratio (DER) representing that how many times the total debts are of total equity. Less the value of DER means less chances of risk and financial distress. Following results indicates that public sector banks used 12.93 time debts, private banks 10.64 times, specialized banks 34.93 times, foreign banks 6.09 times, microfinance banks 3.09 time and investment banks -5.64 times. Therefore, due to the lowest value investment banks dominating on all other banks with reference to utilization of debts in total equity. (Ref Table- 7)

\section{h. Debt to Total Assets Ratio (DTAR):}

Utilization of debts used to finance the total assets is called Debt to Total Assets Ratio (DTAR). Higher the value of DTAR means higher risk and lower the value of DTAR indicates lower risk. According to the following results to finance Rs. 100 assets, 
public sector bank used Rs. 89.88 debts, private bank Rs. 91.05, specialized banks Rs. 78.40, foreign banks Rs. 85.43, microfinance banks Rs. 77.56 and investment banks Rs. 92.33. Finally, microfinance banks dominating on all banks because the value of DTAR of microfinance banks is Rs. 77.56 which is less than all banks. (Ref Table- 8)

\section{i. Equity Multiplier (EM):}

How many times the total assets are of the total shareholder equity is called Equity Multiplier (EM). Significant positive relationship between the Equity Multiplier (EM) and risk was observed. Higher the value of EM means higher risk and vice versa. Following results indicates that assets of public sector banks 14.38 times of shareholder equity, private banks EM 11.68 time, specialized banks 39.13 times, foreign banks 7.10 times, microfinance banks 3.98 time and investment banks -5.26 times. Finally, investment banks dominating on all other banks due to lower value of Equity Multiplier (EM). (Ref Table- 9)

\section{j. Conclusion:}

Following table indicates the overall results and mean value of profitability ratios, liquidity ratios and risk $\&$ solvency ratios. According to mean value of profitability ratios specialized banking sector dominating on all other banking sector because the mean value of all profitability ratios of specialized banking sector is 43.91 which is higher than all other banking sector. Foreign banks dominating on all banking sector with reference to liquidity position as the mean value of liquidity ratios of foreign banks is 28.76 which is greater than all other banking sectors. On the contrary, Mean value of risk \& solvency ratios of investment banking sector is 27.14 which is less than the mean value of all other banking sector. This implies that investment banking sector dominates on all other banking sector with reference to risk $\&$ solvency positions. (Ref Table- 10)

\section{k. Overall Performance:}

Following tables indicates the overall performance of all banking sectors working in Pakistan on the basis of profitability, liquidity and risk \& solvency. According to the overall results and mean value of all types of ratio foreign banking sector dominating on all other banking sector as the mean value of overall performance of foreign banks 9.25 which is higher than all other banking sector. (Ref Table- 11)

\section{REFERENCE:}

Samad, Abdus, and Kabir Hassan (2000), "The Performance of Malaysian Islamic Bank During 1984-1997: 
An Exploratory Study." Thoughts

on Economics 10, no. 1 \& 2: 7-26.

Samad, Abdus (2004), "Performance of Interest-free Islamic banks vis-àvis Interest-based Conventional Banks of Bahrain.” IIUM Journal of Economics and Management 12, no.2: 1-15.

Kader, Janbota M., and Asarpota, Anju K. (2007), "Comparative Financial Performance of Islamic vis-à-vis Conventional Banks in the UAE." Paper presented at 2006-2007 Annual Student Research Symposium \& First Chancellor's Undergraduate Research Award at UAE University.

Moin, S.M. (2008). Performance of Islamic Banking and Conventional Banking in Pakistan:

A Comparative Study. Skovade: University of Skovade school of technology and society.

Metwally, M.M. (1997). Differences between the Financial Characteristics of Interest-Free

Banks and Conventional Banks. European Business Review, 97(2), 92-98.
Iqbal, M. (2001). Islamic and Conventional Banking in the 1990s: A Comparative Study. M.

Iqbal, Islamic Banking and Finance: Current Development in Theory and Practice, United Kingdom: The Islamic Foundation.

Hassan, M.K., \& Bashir, A.H.M. (2003). Determinants of Islamic Banking Profitability.

Paper presented at the Economic Research Forum (ERF) $10^{\text {th }}$ Annual Conference, 16th-18th December 2003, Marrakech: Morocco.

Samad, A. and Hassan, M.K. (1999). The Performance of Malaysian Islamic Bank during

1984-1997: An Exploratory Study. International Journal of Islamic Financial Services, 1(3).

Awan, A., (2009). Comparison Of Islamic And Conventional Banking In Pakistan, Proceedings $2^{\text {nd }} C B R C$, Lahore, Pakistan ,November 14, 2009.

Javaid, S., Anwar, J., \& Zaman, K., (2011). Determinants Of Bank Profitability In Pakistan: Internal 
Factor Analysis. Mediterranean Journal Of Social Sciences2: 1.

Gul, S., Irshad, F., \& Zaman, K., (2011). Factors Affecting Bank Profitability in Pakistan. The Romanian Economic Journal39.

Hempel, George H., and Donald G. Simonson. Bank Management. New York: John Wiley and Sons, Inc., 1998.

Flamini, C., Valentina C., McDonald, G., Liliana, S. (2009) The Determinants of Commercial Bank Profitability in
Sub-Saharan Africa. IMF Working Paper.

Alexandru, C., Genu, G., Romanescu, M.L. (2008), The Assessment of Banking PerformancesIndicators of Performance in Bank Area. MPRA Paper No. 11600.

Khrawish, H.A. (2011) Determinants of Commercial Banks Performance: Evidence from Jordan. International Research Journal of Finance and Economics. Zarqa University, 5(5), 19-45.

\section{Appendix.}

\begin{tabular}{|c|c|c|}
\hline Sr.\# & Banking Sector & Name of Banks \\
\hline \multirow{5}{*}{1} & \multirow{5}{*}{ Public Sector Banks } & First Women Bank Ltd. \\
\hline & & National Bank of Pakistan (NBP) \\
\hline & & Sindh Bank Ltd. \\
\hline & & The Bank of Khyber \\
\hline & & The Bank of Punjab. \\
\hline \multirow{9}{*}{2} & \multirow{9}{*}{ Private Sector Banks } & Albarka Bank Pakistan Ltd. \\
\hline & & Allied Bank Ltd (ABL). \\
\hline & & Askari Bank Ltd. \\
\hline & & Bank Al-Habib Ltd. \\
\hline & & Bank Al-Falah Ltd. \\
\hline & & Bank Islami Pakistan Ltd. \\
\hline & & Burj Bank Ltd. \\
\hline & & Dubai Islami Bank Pakistan Ltd. \\
\hline & & Faysal Bank Ltd. \\
\hline
\end{tabular}




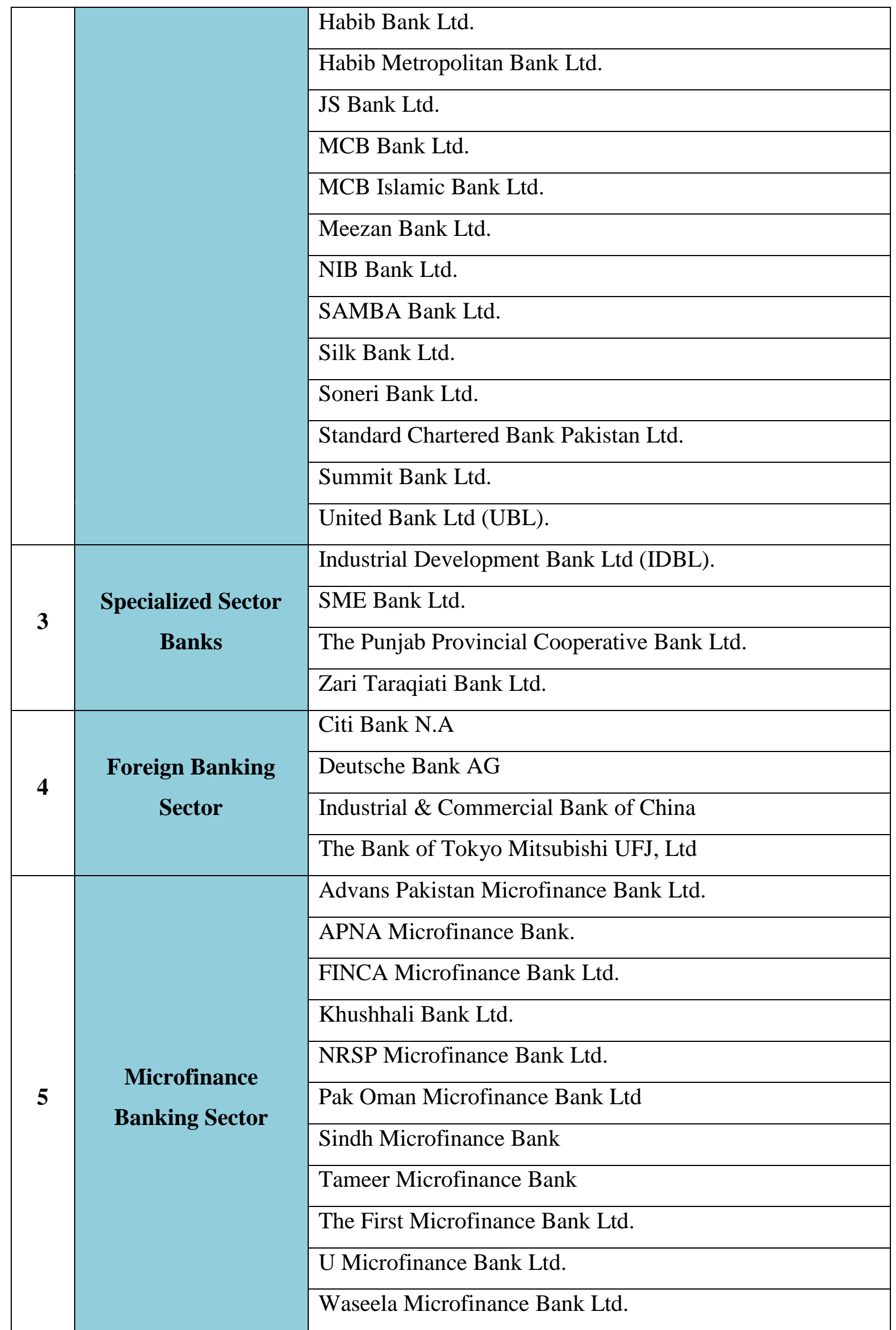




\begin{tabular}{|c|c|c|}
\hline \multirow{5}{*}{6} & \multirow{5}{*}{$\begin{array}{c}\text { Investment Banking } \\
\text { Sector }\end{array}$} & Escorts Investment Bank Ltd. \\
\hline & & First Credit \& Investment Bank. \\
\hline & & First Dawood Investment Bank Ltd. \\
\hline & & IGI Investment Bank Ltd. \\
\hline & & Invest Capital Bank Ltd. \\
\hline
\end{tabular}

\section{LIST OF FIGURES}

Figure- 1

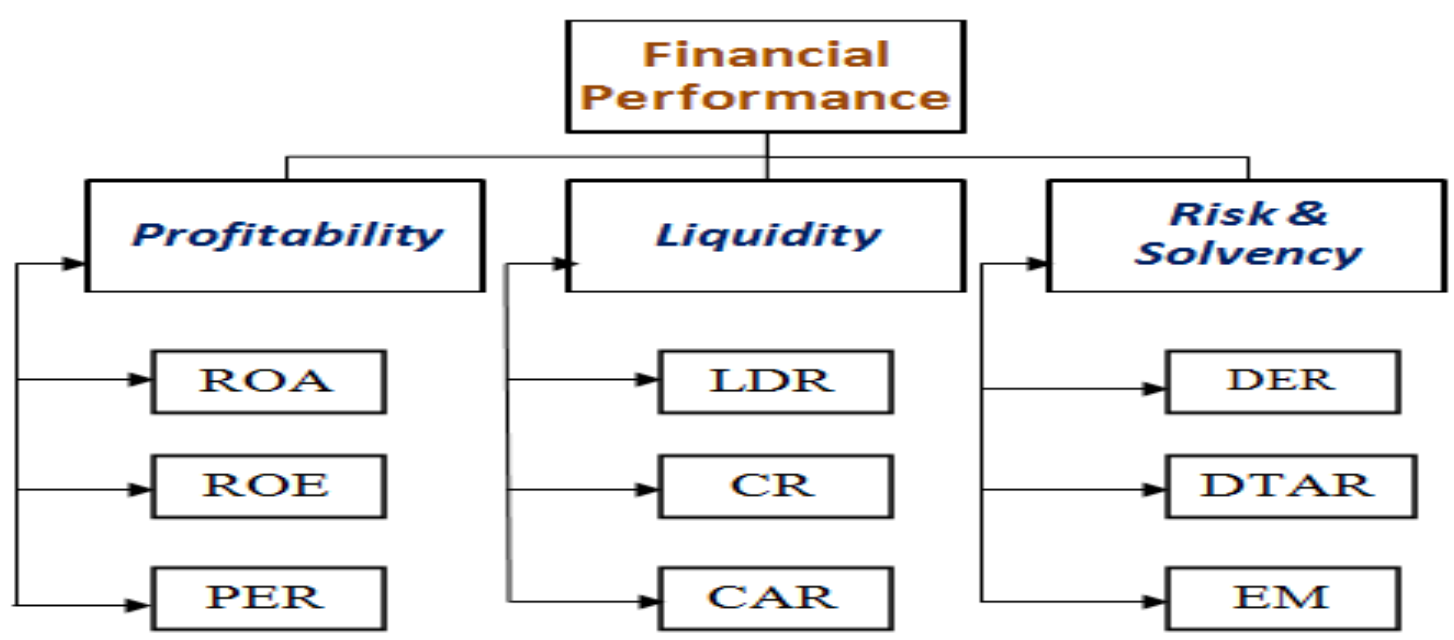

\subsection{Sample of the Study:}

\begin{tabular}{|c|c|c|c|}
\hline Sr.\# & Categories of Banks & $\begin{array}{l}\text { No. of } \\
\text { Banks }\end{array}$ & Data \\
\hline 1 & Public Sector Banks & 05 & \multirow{6}{*}{$\begin{array}{c}\text { Data from } 2010 \text { to } 2014 \text { used for } \\
\text { ratio analysis }\end{array}$} \\
\hline 2 & Private Banks & 22 & \\
\hline 3 & Specialized Banks & 04 & \\
\hline 4 & Foreign Banks & 04 & \\
\hline 5 & Microfinance Banks & 11 & \\
\hline 6 & Investment Banks & 07 & \\
\hline
\end{tabular}

Note: Detailed of each Categories of banks are given in appendix section. 
ELK ASIA PACIFIC JOURNAL OF FINANCE AND RISK MANAGEMENT

ISSN 2349-2325 (Online); DOI: 10.16962/EAPJFRM/issn. 2349-2325/2015; Volume 9 Issue 4 (2018)

\section{LIST OF TABLES}

TABLE 1: Comparative Analysis of ROA of selected banks

\begin{tabular}{|c|c|c|c|c|c|c|c|}
\hline \multicolumn{8}{|c|}{ Return on Assets (ROA) } \\
\hline \multirow{5}{*}{ 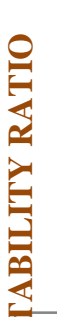 } & \multirow{5}{*}{$\begin{array}{r}10.00 \\
5.00 \\
0.00 \\
-5.00 \\
-10.00 \\
-15.00\end{array}$} & \multicolumn{6}{|c|}{\begin{tabular}{|l|l} 
\\
\end{tabular}} \\
\hline & & \multicolumn{6}{|c|}{ 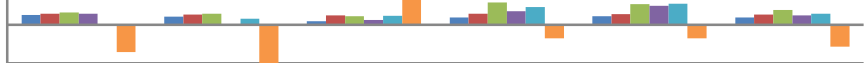 } \\
\hline & & \multirow{2}{*}{\multicolumn{6}{|c|}{\begin{tabular}{|l|l|l} 
\\
\end{tabular}}} \\
\hline & & & & \multirow[b]{2}{*}{2013} & \multirow[b]{2}{*}{2014} & & \\
\hline & & 2011 & 2012 & & & 2015 & $\begin{array}{l}\text { Mean } \\
\text { Value }\end{array}$ \\
\hline \multicolumn{2}{|c|}{ Public Sector Bank } & \multicolumn{6}{|c|}{1.26901431 .05224930 .45805490 .92872141 .12033390 .9656747} \\
\hline \multicolumn{2}{|c|}{ Private Sector Bank } & \multicolumn{6}{|c|}{1.41609641 .3011731 .22691021 .42576091 .37328921 .3486459} \\
\hline \multicolumn{2}{|c|}{ Specialized Banks } & \multicolumn{6}{|c|}{$1.60090641 .42114921 .110000 \not 2.8781192 .67209981 .9364551$} \\
\hline \multicolumn{2}{|c|}{ Foreign Banks } & \multicolumn{6}{|c|}{$1.4337749-0.0702510 .60857731 .73577032 .47106941 .2357882$} \\
\hline \multicolumn{2}{|c|}{ Microfinance Banks } & \multicolumn{6}{|c|}{$0.07948790 .76602311 .19011532 .293383 \not 2.70850831 .4075037$} \\
\hline \multicolumn{2}{|c|}{ Investment Banks } & \multicolumn{6}{|c|}{$-3.519057-13.349646 .2075241-1.726132-1.738078-2.825076$} \\
\hline
\end{tabular}

TABLE 2: Comparative Analysis of ROE of selected banks

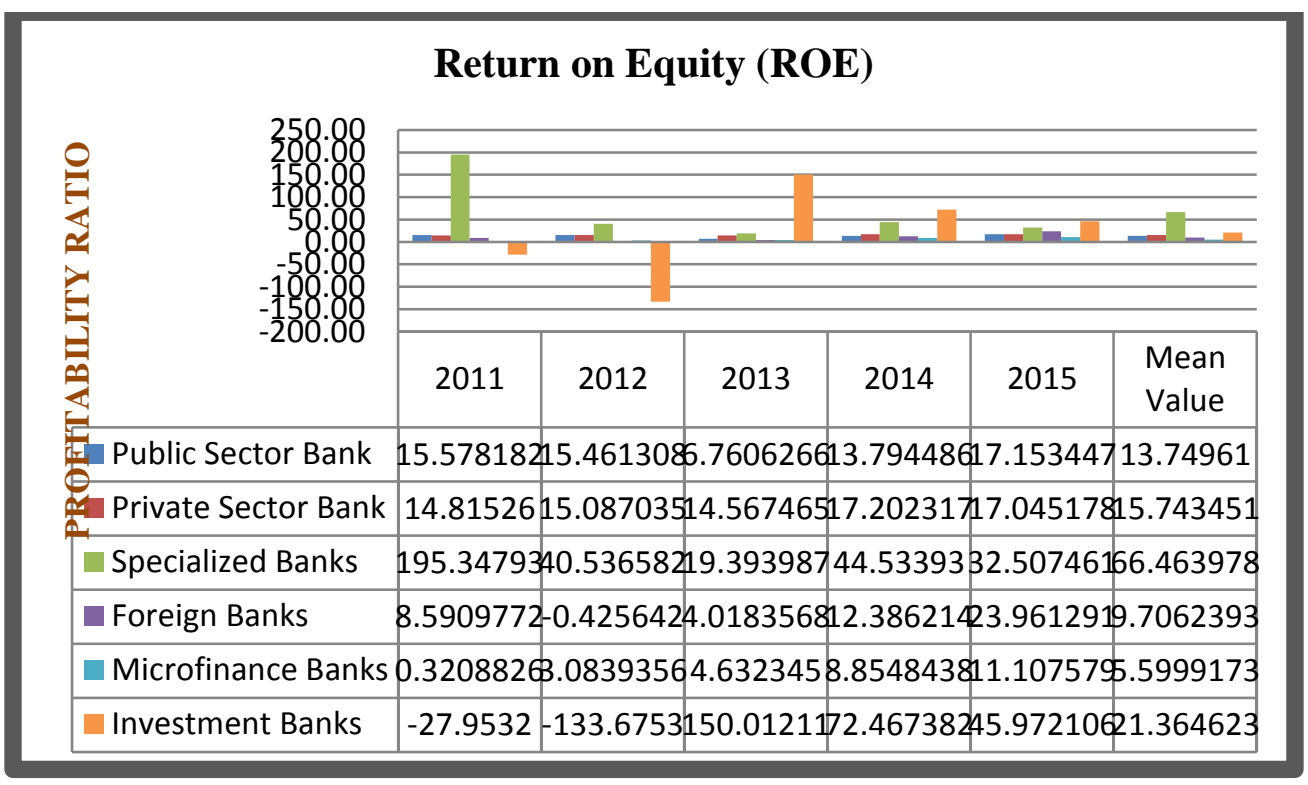


TABLE 3: Comparative Analysis of PER of selected banks

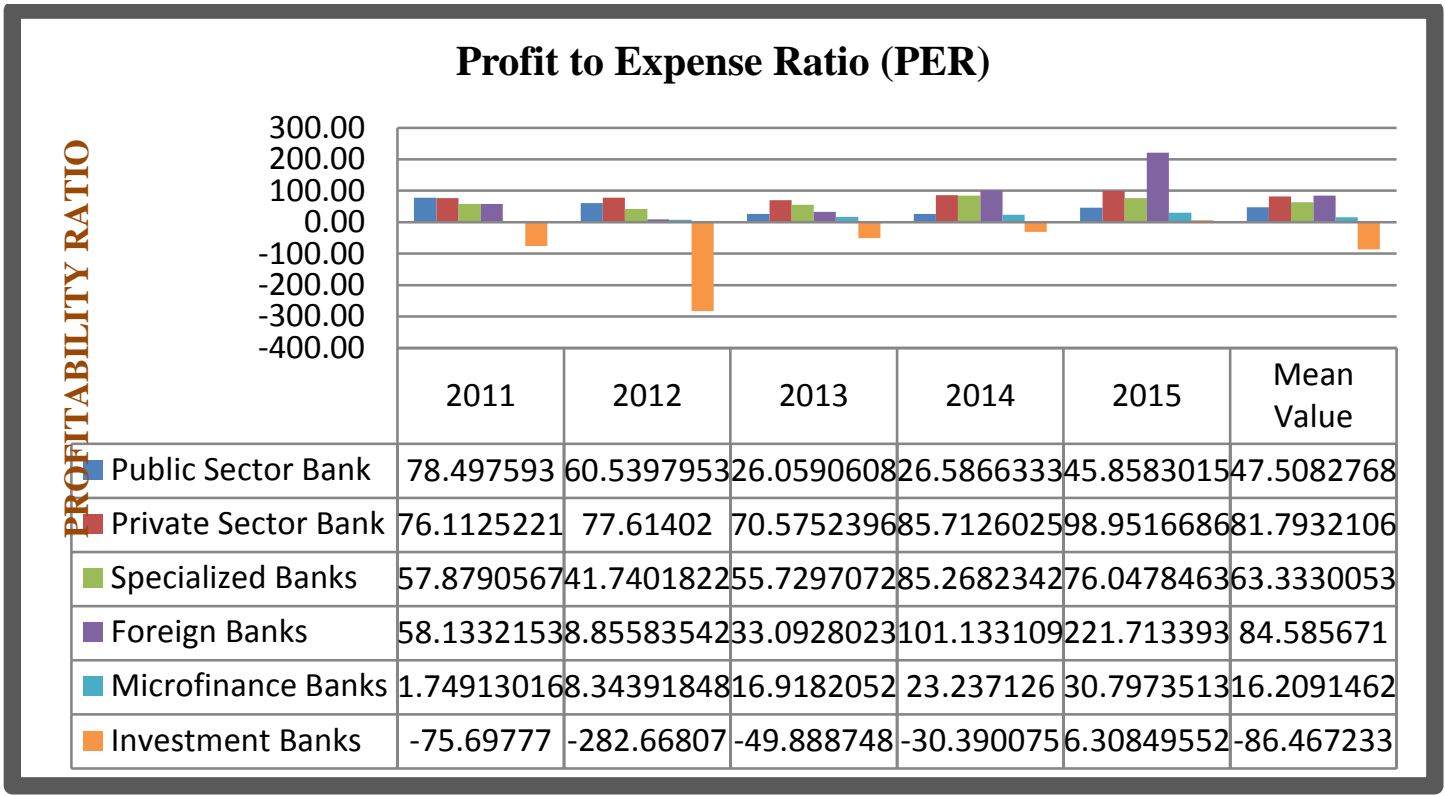

TABLE 4: Comparative Analysis of LDR of selected banks

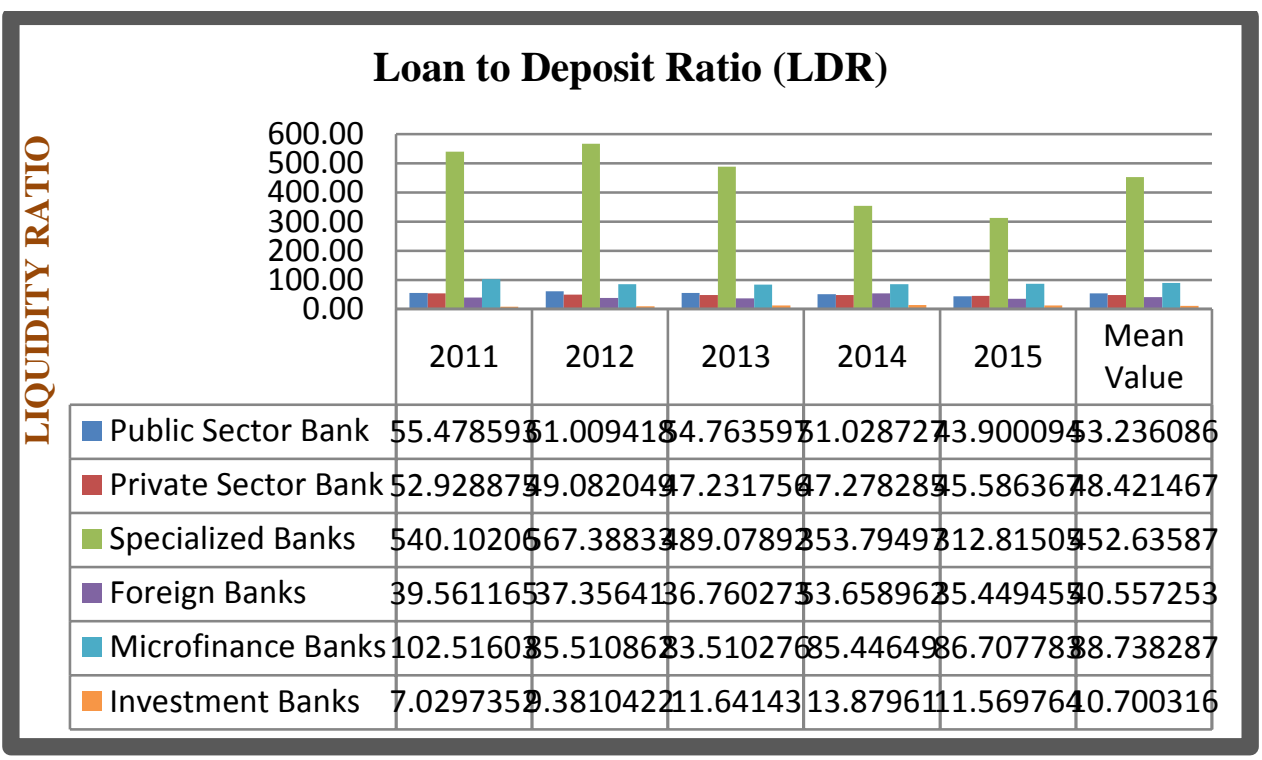


ELK ASIA PACIFIC JOURNAL OF FINANCE AND RISK MANAGEMENT

ISSN 2349-2325 (Online); DOI: 10.16962/EAPJFRM/issn. 2349-2325/2015; Volume 9 Issue 4 (2018)

TABLE 5: Comparative Analysis of CR of selected banks

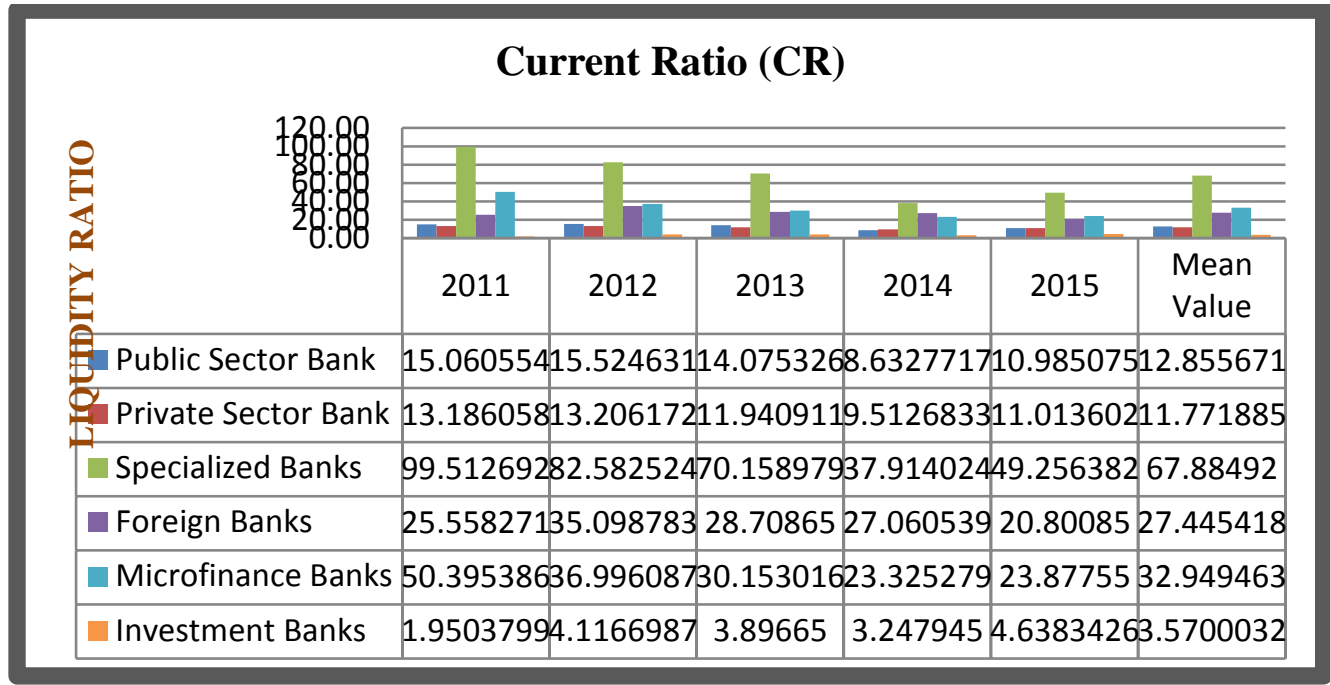

TABLE 6: Comparative Analysis of CAR of selected banks

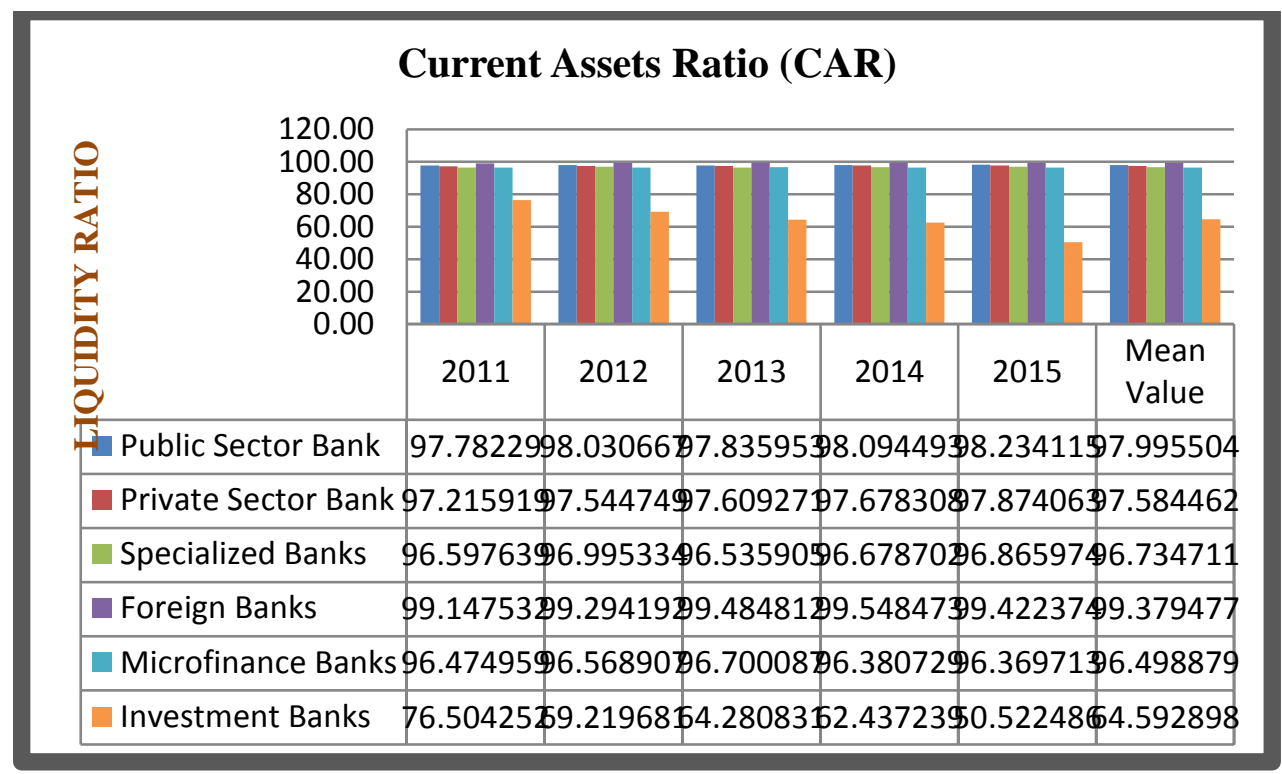


ELK ASIA PACIFIC JOURNAL OF FINANCE AND RISK MANAGEMENT

ISSN 2349-2325 (Online); DOI: 10.16962/EAPJFRM/issn. 2349-2325/2015; Volume 9 Issue 4 (2018)

TABLE 7: Comparative Analysis of DER of selected banks

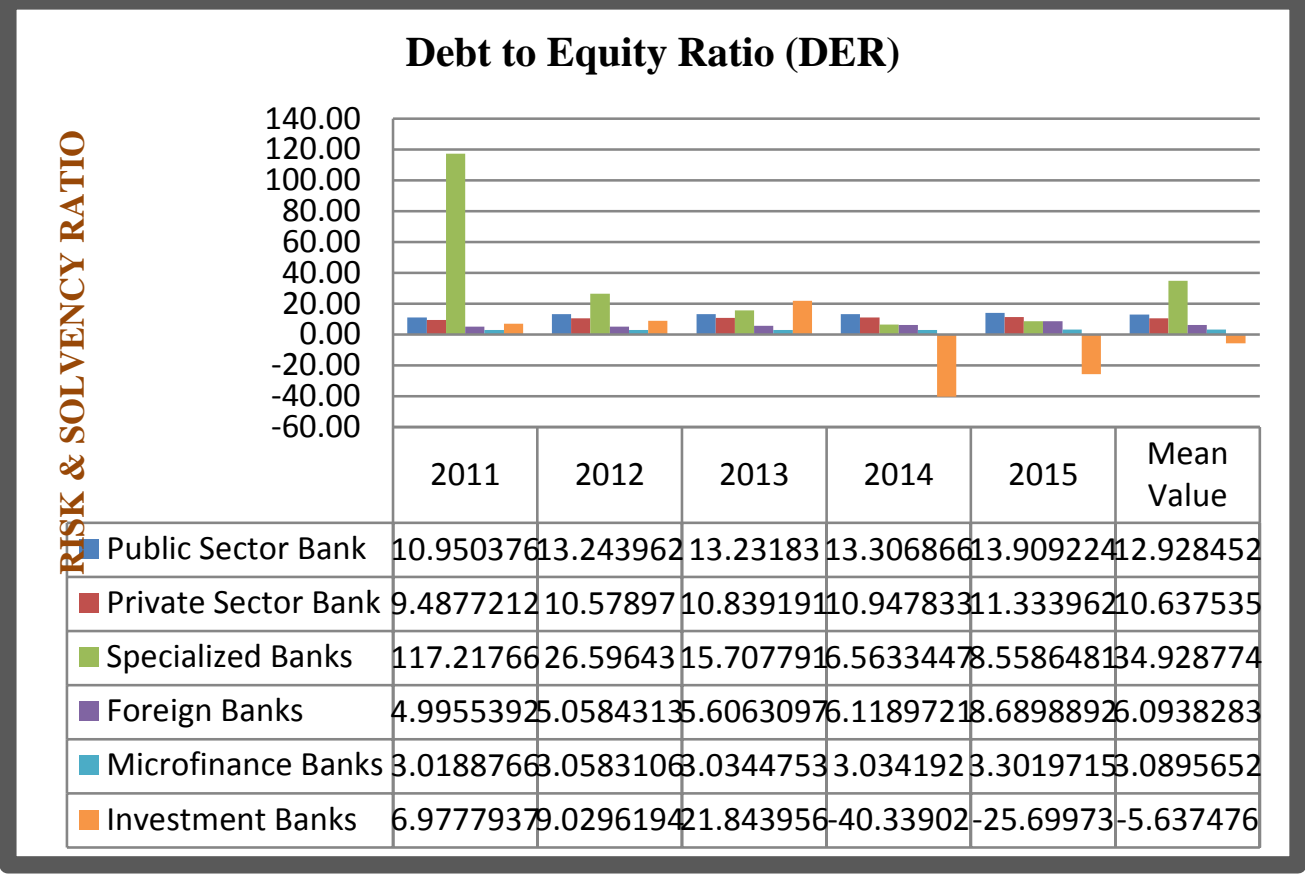

TABLE 8: Comparative Analysis of DTAR of selected banks

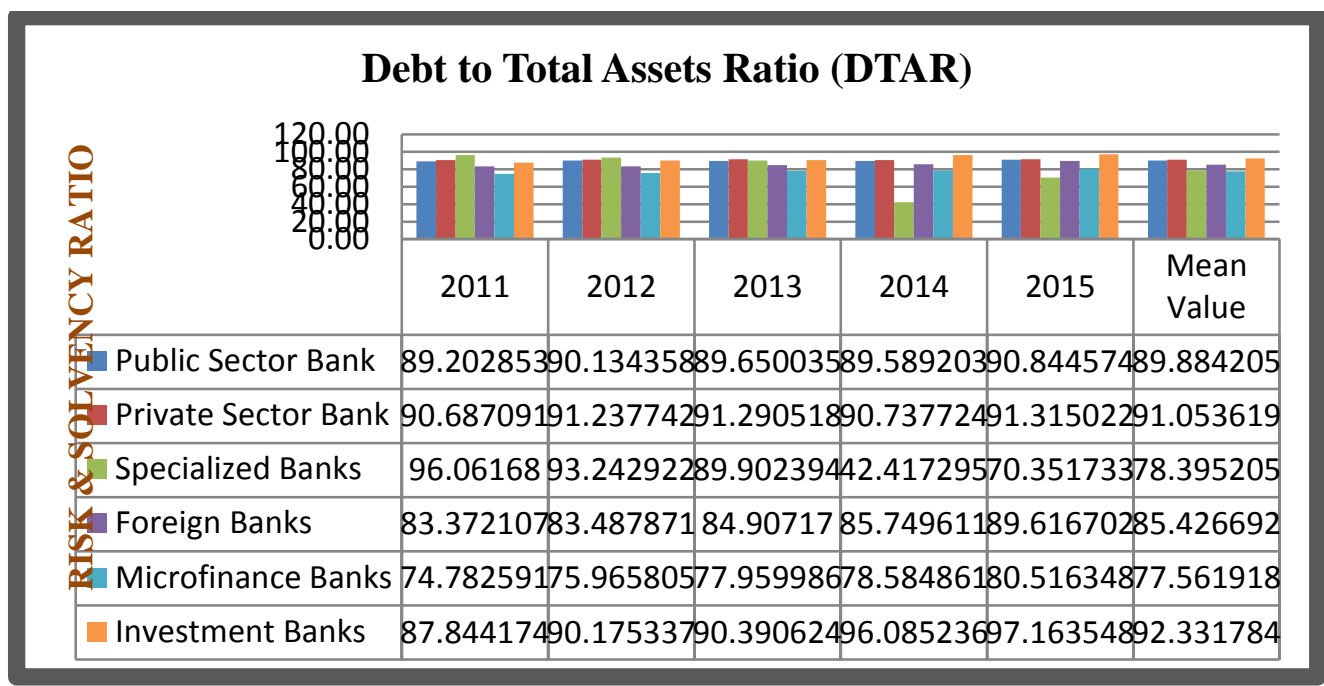


TABLE 9: Comparative Analysis of EM of selected banks

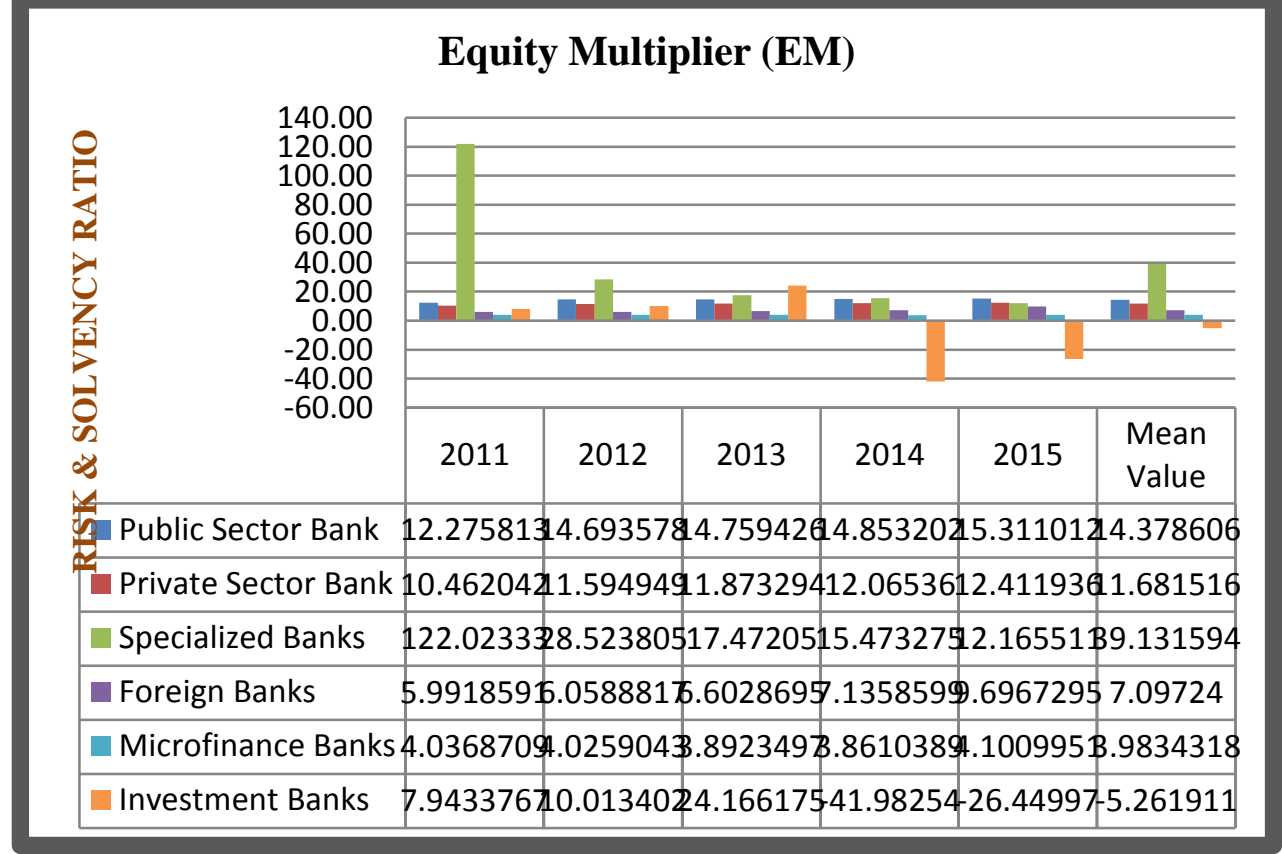

TABLE 10: Comparative Ratio analysis of selected banks

\begin{tabular}{|l|c|c|c|c|c|c|}
\hline RATIO & $\begin{array}{c}\text { Public } \\
\text { Sector } \\
\text { Bank }\end{array}$ & $\begin{array}{c}\text { Private } \\
\text { Sector } \\
\text { Bank }\end{array}$ & $\begin{array}{c}\text { Specialized } \\
\text { Banks }\end{array}$ & $\begin{array}{c}\text { Foreign } \\
\text { Banks }\end{array}$ & $\begin{array}{c}\text { Microfinance } \\
\text { Banks }\end{array}$ & $\begin{array}{c}\text { Investment } \\
\text { Banks }\end{array}$ \\
\hline ROA & 0.97 & 1.35 & 1.94 & 1.24 & 1.41 & -2.83 \\
\hline ROE & 13.75 & 15.74 & 66.46 & 9.71 & 5.60 & 21.36 \\
\hline PER & 47.51 & 81.79 & 63.33 & 84.59 & 16.21 & -86.47 \\
\hline Mean & $\mathbf{2 0 . 7 4}$ & $\mathbf{3 2 . 9 6}$ & $\mathbf{4 3 . 9 1}$ & $\mathbf{3 1 . 8 5}$ & $\mathbf{7 . 7 4}$ & $\mathbf{- 2 2 . 6 4}$ \\
\hline CR & 12.86 & 11.77 & 67.88 & 27.45 & 32.95 & 3.57 \\
\hline CAR & 98.00 & 97.58 & 96.73 & 99.38 & 96.50 & 64.59 \\
\hline LDR & $(53.24)$ & $\mathbf{4 8 . 4 2 )}$ & $\mathbf{( 4 5 2 . 6 4 )}$ & $\mathbf{( 4 0 . 5 6 )}$ & $(88.74)$ & $(10.70)$ \\
\hline Mean & $\mathbf{1 9 . 2 1}$ & $\mathbf{2 0 . 3 1}$ & $\mathbf{- 9 6 . 0 1}$ & $\mathbf{2 8 . 7 6}$ & $\mathbf{1 3 . 5 7}$ & $\mathbf{1 9 . 1 5}$ \\
\hline DER & 12.93 & 10.64 & 34.93 & 6.09 & 3.09 & -5.64 \\
\hline DTAR & 89.88 & 91.05 & 78.40 & 85.43 & 77.56 & 92.33 \\
\hline EM & 14.38 & 11.68 & 39.13 & 7.10 & 3.98 & -5.26 \\
\hline Mean & $\mathbf{3 9 . 0 6}$ & $\mathbf{3 7 . 7 9}$ & $\mathbf{5 0 . 8 2}$ & $\mathbf{3 2 . 8 7}$ & $\mathbf{2 8 . 2 1}$ & $\mathbf{2 7 . 1 4}$ \\
\hline
\end{tabular}


TABLE 11: Overall performance of selected banks

\begin{tabular}{|l|c|c|c|c|c|c|c|}
\hline \multicolumn{1}{|c|}{ Mean Value } & $\begin{array}{c}\text { Public } \\
\text { Sector } \\
\text { Bank }\end{array}$ & $\begin{array}{c}\text { Private } \\
\text { Sector } \\
\text { Bank }\end{array}$ & $\begin{array}{c}\text { Specialized } \\
\text { Banks }\end{array}$ & $\begin{array}{c}\text { Foreign } \\
\text { Banks }\end{array}$ & $\begin{array}{c}\text { Microfinance } \\
\text { Banks }\end{array}$ & $\begin{array}{c}\text { Investment } \\
\text { Banks }\end{array}$ \\
\hline $\begin{array}{l}\text { Profitability } \\
\text { Ratio }\end{array}$ & 20.74 & & 32.96 & 43.91 & 31.85 & 7.74 & -22.64 \\
\hline $\begin{array}{l}\text { Liquidity } \\
\text { Ratio }\end{array}$ & 19.21 & & 20.31 & -96.01 & 28.76 & 13.57 & 19.15 \\
\hline $\begin{array}{l}\text { Risk \& } \\
\text { Solvency Ratio }\end{array}$ & $(39.06)$ & & $(37.79)$ & $(50.82)$ & $(32.87)$ & $(28.21)$ & $(27.14)$ \\
\hline $\begin{array}{l}\text { All Ratio } \\
\text { Means }\end{array}$ & $\mathbf{0 . 2 9}$ & & $\mathbf{5 . 1 6}$ & $\mathbf{- 3 4 . 3 1}$ & $\mathbf{9 . 2 5}$ & $\mathbf{- 2 . 3}$ & $\mathbf{- 1 0 . 2 1}$ \\
\hline
\end{tabular}

